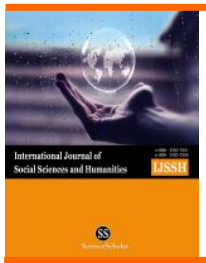

International Journal of Social Sciences and Humanities

Available online at http://sciencescholar.us/journal/index.php/ijssh

Vol. 1 No. 2, August 2017, pages: 43 50

e-ISSN: 2550-7001, p-ISSN: 2550-701X

http://dx.doi.org/10.21744/ijssh.v1i2.36

\title{
An Analysis of Students' Motivation Toward English Learning As Second Language Among Students In Pritchard English Academy (PEACE)
}

\author{
$\underset{\text { Croskich Mar updite }}{\text { Cork }}$ \\ I Wayan Suryasa ${ }^{\text {; }}$ I Gede Putu Adhitya Prayoga ${ }^{\text {b }}$ I Wayan Astu Werdistira c \\ Article history: Received 11 January 2017 ; Accepted in revised form 1 July 2017 ; Approved 25 July 2017 ; \\ Available online 30 August 2017
}

Correspondence Author

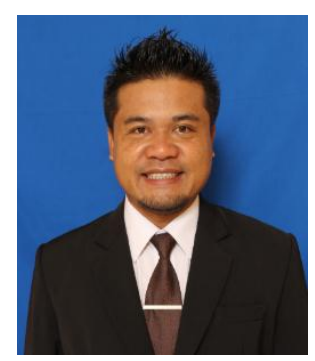

\section{Keywords}

English learning:

motivation;

Pritchard English

Academy;

Second language

learning;

Student;
Abstract

This research aimed at investigating the students' motivation in English learning as a second language. The method used was a survey by randomly asking the students in Pritchard English Academy (PEACE) to fill out a questionnaire which adapted from Attitude Motivation Test Battery (AMTB) designed by R.C. Gardner. The questionnaire was administered to a group of 30 students who come from intermediate until advanced level. The data were analyzed by using SPPS program. It was used to find out mean score and standard deviation. The main findings show that the students are relative "highly" motivated and found to be slightly more "instrumentally" motivated to learn English. This reveals that instrumental motivation is a significant factor among this group of students learning English. Based on this study's findings, some relevant and useful motivational learning implications are recommended for enhancement and improvement of the students' motivation.

e-ISSN : 2550-7001, p-ISSN : 2550-701X@ Copyright 2017. The Author. SS Journals Published by Universidad Técnica de Manabí. This is an open-access article under the CC BY-SA 4.0 license (https://creativecommons.org/licenses/by-sa/4.0/) All rights reserved.

STIMIK STIKOM Bali, Denpasar, Bali - Indonesia iwayansuryasa@gmail.com

b STIMIK STIKOM Bali, Denpasar, Bali - Indonesia

STIMIK STIKOM Bali, Denpasar, Bali - Indonesia 
Contents

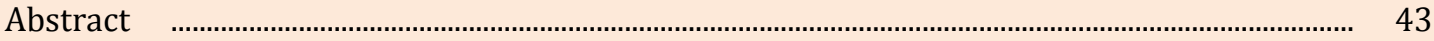

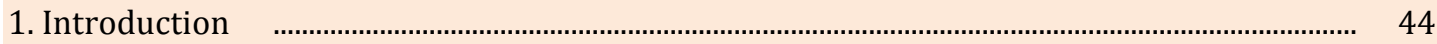

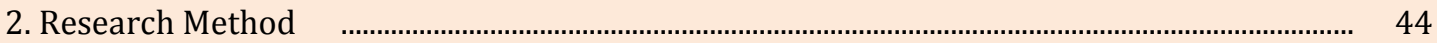

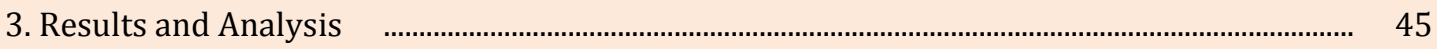

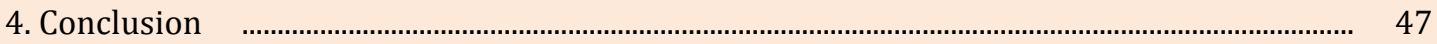

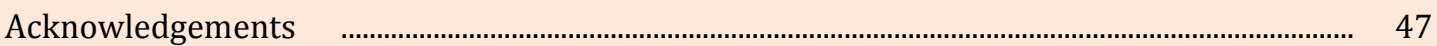

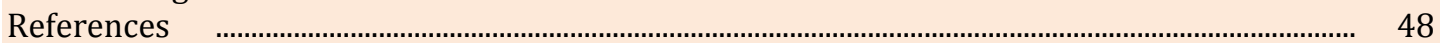

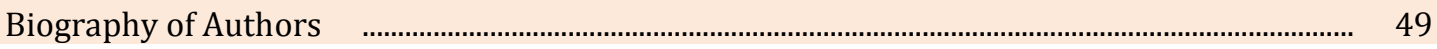

\section{Introduction}

Foreign language teaching, especially English in Indonesia is still far from successful. The students' English proficiency which formally has been studying since elementary school level is still considered as inadequate. It is proven by the findings, such as the students' score in a daily test at school or even national exam are still unsatisfactory. The low frequency of the usage of English among students is also a common thing in this country. It is caused by the feeling of anxiety and less of confident to communicate using English. Based on those problems, it is a must for the teacher to improve the quality of teaching English becomes effective and more efficient for the students.

There are many types of research and theories discussed teaching and learning English in Indonesia. Most of them argue that there are some factors affect the success in teaching English. Those factors are a teacher, students, curriculum, teaching material, and learning facilities. Students are one of the important factors. They learn English because of the motivation that they have. The students' motivation will influence their success in learning. One research related to motivation shows that students' motivation has an important role in carrying the students becomes a success in English.

There are two kinds of motivation in learning English as a second language as proposed by Gardner and Lambert (1972), namely integrative and instrumental motivation. Integrative motivation means the desire to learn a language in order to communicate with people from another culture who speak that language, while Instrumental motivation refers to the desire to learn a language because it would fulfill certain positive goals, such as getting a job, passing an examination, etc.

The research was done by Marlina (2007) which related to students' motivation in learning English as the second language found that most of the students learn English because they want to get a better job, as they know English is an international language. This motivation refers to instrumental motivation which can influence the success in learning English. Pritchard English Academy (PEACE) is a school of English which is located in Dalung, Badung district. It has 75 students which come from elementary until advanced level. Those all students have a different motivation in learning English. This study tries to investigate the level of students' motivation in learning English and also to know whether they predominantly integratively or instrumentally motivated towards English learning.

\section{Research Method}

30 students from Pritchard English Academy (PEACE) were selected as samples. All those students were from two different levels. The level of students was grouped based on the result of placement test in the beginning. In total 30 students who were delivered a questionnaire, 15 students were from the intermediate level, and the other 15 students were from advanced level.

This study is a kind of survey. It is conducted by delivering a questionnaire to each sample. The questionnaire is adapted from Attitude Motivation Test Battery (AMTB) designed by R.C. Gardner. A questionnaire consists of 10 statements, 5 statements for integrative motivation, 5 statements for instrumental motivation. The questionnaire consists of two parts, such as: 
a) Integrative motivation (Cultural and social goals)

There are 5 statements to know whether the students have the integrative motivation or not, such as:

1) Studying English is important because it will make me more educated.

2) Studying English is important because other people will respect me more if I know English.

3) I wish I were fluent in English.

4) I wish I could have many native English speaking friends.

5) I want to learn other culture and understand the world better.

b) Instrumental motivation (Career related and academic goals)

In this type, there are 5 statements to know whether the students have the instrumental motivation or not, such as:

1) Studying English is important because I will need it for my career.

2) Studying English is important because it will be useful in getting a good job.

3) I want to get grade "A" in my English class all the time.

4) If I can speak English, I will use it for entering college abroad.

5) I would feel quite relaxed if I had to give street directions in English.

The students have to respond each statement whether they strongly disagree, disagree, neutral, agree, and strongly agree. The students may choose 'neutral'. There is no right and wrong answer.

The data obtained from the questionnaires were analyzed using the SPSS program. The data concerning subjects' general background as well as their comments were calculated and presented in percentage. A five-point scale was used to measure the level and type of subjects' learning motivation. Such scale was used in the questionnaire to specify the level of the agreement or disagreement based on the following criteria:

Table. 1

Mean Range for Motivation Level

\begin{tabular}{cc}
\hline Mean Range & Interpretation \\
\hline $3.68-5.00$ & High degree of Motivation \\
$2.34-3.67$ & Moderate degree of Motivation \\
$1.00-2.33$ & Low degree of Motivation \\
\hline
\end{tabular}

\section{Results and Analysis}

This part presents overall details of the study's results. The following two tables (Table 2 and 3 ) outlines all the 10 statements, their resulting itemized mean scores, using descriptive statistics of Mean scores and Standard Deviation (S.D.) and their corresponding motivation levels, which serve as the basis for further interpretation and implications. The following Table 2 contains 5 instrumentally motivated related items.

Table 2

Instrumental Motivation

\begin{tabular}{llccc}
\hline No & \multicolumn{1}{c}{ Instrumental Motivation } & Mean & S.D & $\begin{array}{c}\text { Rating of } \\
\text { Motivational } \\
\text { Level }\end{array}$ \\
\hline 1 & $\begin{array}{l}\text { Studying English is important because it will make } \\
\text { me more educated. }\end{array}$ & 4.43 & 0.91 & High \\
2 & $\begin{array}{l}\text { Studying English is important because other people } \\
\text { will respect me more if I know English. }\end{array}$ & 4.53 & 0.50 & High \\
\hline
\end{tabular}

Suryasa, I. W., Prayoga, I. G. P. A., \& Werdistira, I. W. A. (2017). An analysis of students motivation toward English learning as second language among students in Pritchard English academy (PEACE). International Journal of Social Sciences and Humanities, 1(2), 43-50. https://doi.org/10.29332/ijssh.v1n2.36 


\begin{tabular}{lllll}
\hline 3 & I wish I were fluent in English. & 4.30 & 0.75 & High \\
4 & $\begin{array}{l}\text { I wish I could have many native English speaking } \\
\text { friends. }\end{array}$ & 4.10 & 0.60 & High \\
5 & & & High \\
& $\begin{array}{l}\text { I want to learn other culture to understand the } \\
\text { world better. }\end{array}$ & 4.57 & 0.92 & High \\
\hline
\end{tabular}

Table 2 reveals that the respondents possessed a high level of instrumental motivation. This is clearly seen by the average mean score of 4.38 in the table. Statement number 5 has the highest mean (4.57). The statement number 2 has an average mean score of 4.53. The statement number 1 has an average mean score of 4.43. And the statement number 3 has an average mean score of 4.30. The lowest mean score of 4.10 is statement number 4. However, the overall mean score of instrumental motivation demonstrates a high level of motivation.

Table 3

Integrative Motivation

\begin{tabular}{llccc}
\hline No & \multicolumn{1}{c}{ Integrative Motivation } & Mean & S.D & $\begin{array}{c}\text { Rating of } \\
\text { Motivational } \\
\text { Level }\end{array}$ \\
\hline 6 & $\begin{array}{l}\text { Studying English is important because I will need it } \\
\text { for my career. }\end{array}$ & 4.80 & 0.40 & High \\
7 & $\begin{array}{l}\text { Studying English is important because it will be } \\
\text { useful in getting a good job. }\end{array}$ & 4.17 & 0.50 & High \\
$8 \quad \begin{array}{l}\text { I want to get grade "A" in my English class all the } \\
\text { time. }\end{array}$ & 4.23 & 0.62 & High \\
9 & $\begin{array}{l}\text { If I can speak English, I will use it for entering } \\
\text { collage abroad. }\end{array}$ & 4.37 & 0.71 & High \\
10 & $\begin{array}{l}\text { I would feel quite relaxed if I had to give street } \\
\text { directions in English. }\end{array}$ & 3.57 & 0.50 & Moderate \\
\hline$\quad$ Total & $\mathbf{4 . 2 2}$ & $\mathbf{0 . 5 7}$ & High \\
\hline
\end{tabular}

Table 3 reveals that the respondents possessed a high level of integrative motivation. This is clearly seen by the average mean score of 4.22 in the table. Statement number $6,9,8$, and 7 show the highest level of integrative motivation with the mean scores of 4.80, 4.37, 4.23, and 4.17. The statement number 10 has the lowest mean score which is 3.57 and is considered as a moderate level of motivation.

Table 4

The Comparison between Instrumental and Integrative Motivation

\begin{tabular}{cccc}
\hline Motivation & Mean & S.D. & Meaning \\
\hline Instrumental Motivation & 4.38 & 0.71 & High \\
Integrative Motivation & 4.22 & 0.57 & High \\
Total & $\mathbf{4 . 3 0}$ & $\mathbf{0 . 6 4}$ & High \\
\hline
\end{tabular}

Table 4 presents the comparison between instrumental and integrative motivation. It reveals that the mean score of instrumental motivation (4.38) is higher than the mean score of integrative motivation (4.22). However, the overall mean scores of both types of the motivation of 4.30 are considered as a high degree of motivation.

The overall results reveal that the students are highly motivated to learn English. This finding answers the research question of what the level of the subjects' motivation is. Based on the 
comparison and assessment, it is discovered that the students are slightly more strongly instrumentally motivated to learn English. This finding has relevant implications and should be recommended for further training or studies.

Based on the findings of this study, the results are unique for these particular students: i.e their high motivation in both instrumental and integrative aspects and even with a slight dominance in instrumental motivation. Moreover, the study of students in other institutions with largely different context may results significantly different. Further researchers should also include more and several of institutions or school, both international and national.

As the English learning motivation is one of the most important learning factors, the need to determine the actual motivational situations of any students group is useful. This is for the benefit of their language-learning effectiveness and proficiency.

\section{Conclusion}

In conclusion, this study was conducted to provide some insights into the level and type of motivation of the students at Pritchard English Academy (PEACE). Using the survey method, the questionnaires were proposed by Gardner's (1985) 'Attitude Motivation Test Battery (AMTB),' and then were analyzed by using SPSS program.

The study provides useful knowledge and information for the institute to improve their English courses. Motivation in English language learning of the students can be a great source of knowledge and understanding to implement relevant programs or activities to stimulate the more motivating learning atmosphere. Students with adequate motivation will become efficient language learners with ultimate language proficiency.

\section{Acknowledgement}

Authors would like to give huge thanks to the people who involved in this study for the advice so this study could be done properly.

Suryasa, I. W., Prayoga, I. G. P. A., \& Werdistira, I. W. A. (2017). An analysis of students motivation toward English learning as second language among students in Pritchard English academy (PEACE). 


\section{References}

Adetunji, A. T., Adetunji, A. V., Adeleke, E. O., \& Madubuike, S. C. (2017). Deregulation: The Effect of Market-led Approach to Nigerian Universities Management. International Journal of Social Sciences and Humanities (IJSSH), 1(1), 1-8.

Amerta, I. M. S. (2017). The Role of Tourism Stakeholders at Jasri Tourism Village Development, Karangasem Regency. International Journal of Social Sciences and Humanities (IJSSH), 1(2), 20-28.

Astawa, I. N., Mantra, I. B. N., \& Widiastuti, I. A. M. S. (2017). Developing Communicative English Language Tests for Tourism Vocational High School Students. International Journal of Social Sciences and Humanities (IJSSH), 1(2), 58-64.

Basak, A., \& Khanna, K. (2017). A Study on the Selection Criteria of Different Hotels of Delhi NCR in Accordance to the HR Policies and Market Trends. International Journal of Social Sciences and Humanities (IJSSH), 1(1), 27-38.

Billaiya, R., Malaiya, S., \& Parihar, K. S. (2017). Impact of Socio Economic Trends on Students in Quality Education System. International Journal of Social Sciences and Humanities (IJSSH), 1(1), 16-20.

Cedeño, M. L. D., Arteaga, M. G. D., Pérez, A. V., \& Arteaga, M. L. D. (2017). Regulatory Framework for Renewable Energy Sources in Ecuador Case Study Province of Manabí. International Journal of Social Sciences and Humanities (IJSSH), 1(2), 29-42.

Gámez, M. R., Pérez, A. V., Será, A. S., \& Ronquillo, Z. M. (2017). Renewable Energy Sources and Local Development. International Journal of Social Sciences and Humanities (IJSSH), 1(2), 10 19.

Gardner, R. \& Lambert, W. 1972. Attitudes and Motivation in Secondary Language Learning. Rowley, M. A: Newbury House.

Gardner, R. C. 1985. The Attitude Motivation Test Battery: Technical Report 1.University of Western Ontario: London.

Ghosh, C. (2017). A Study on-Evaluating Marketing Strategies Adopted by Home Appliance for Economic Development in India. International Journal of Social Sciences and Humanities (IJSSH), 1(1), 9-15.

Harmer, J. (1991). The practice of English language teaching. London: Longman

Hedge, T. (2000). Teaching and learning in the language classroom. Oxford: United Kingdom: Oxford University Press.

Horwitz, E. K. (1990). Attending to the affective domain in the foreign language classroom: Shifting the instructional focus to the learner. Middlebury, VT: Northeast Conference of foreign language teachers.

Lightbown, P.M., \& Spada, N. (1999). How languages are learned. Oxford: Oxford University.

Maba, W. (2017). Teacher's Perception on the Implementation of the Assessment Process in 2013 Curriculum. International Journal of Social Sciences and Humanities (IJSSH), 1(2), 1-9.

Maba, W., \& Mantra, I. B. N. (2017). An Analysis of Assessment Models Employed by The Indonesian Elementary School Teachers. International Journal of Social Sciences and Humanities (IJSSH), 1(1), 39-45.

Marlina, Lenny. 2007.Motivation and Language Learning: A Case of EFL Students. Jurnal KOLITA. Unika Atma Jaya.

Parsons, R., Hinson, S., Brown, D. (2001). Educational psychology: practitioner - researcher models of teaching. University of Virginia: Wadsworth Thomson Learning.

Siriluck Wechsumangkalo and Sirithip Prasertrattanadecho (2002). Integrative motivation, instrumental motivation, and English achievement among students in the Faculty of Arts. Unpublished master's thesis, School of Language and Communication. National Institute of Development Administration.

Spolsky, B. (1990). Conditions for second language learning. Hong Kong: Oxford University Press.

Suparsa, I. N., Mantra, I. B. N., \& Widiastuti, I. A. M. S. (2017). Developing Learning Methods of Indonesian as a Foreign Language. International Journal of Social Sciences and Humanities (IJSSH), 1(2), 51-57. 


\section{Web source:}

http://www.brighthubeducation.com/language-learning-tips/70729-defining-second-languageacquisition/ (Accessed on December, 21 ${ }^{\text {st }} 2014$ )

\section{Biography of Authors}

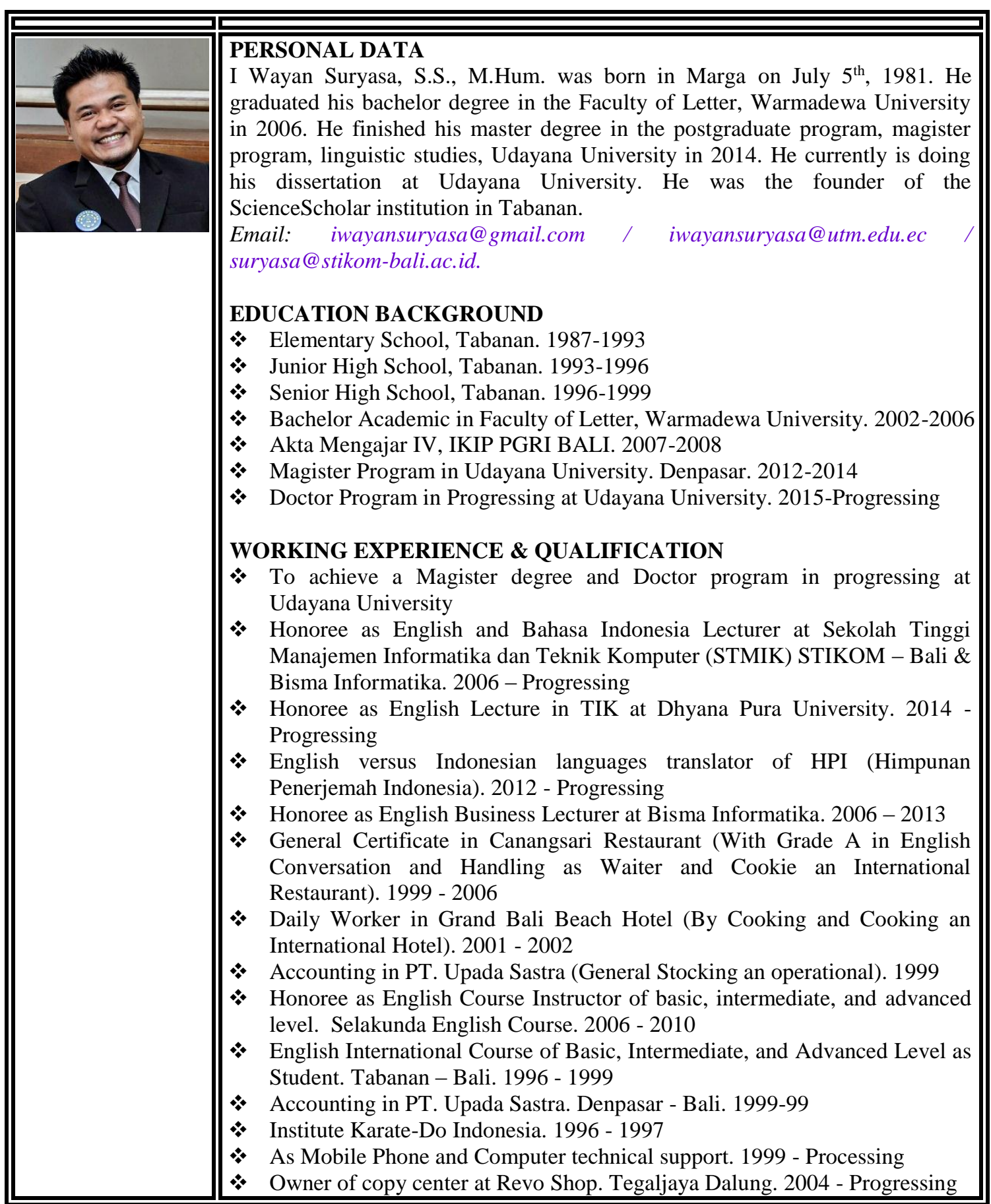

Suryasa, I. W., Prayoga, I. G. P. A., \& Werdistira, I. W. A. (2017). An analysis of students motivation toward English learning as second language among students in Pritchard English academy (PEACE). International Journal of Social Sciences and Humanities, 1(2), 43-50. https://doi.org/10.29332/ijssh.v1n2.36 


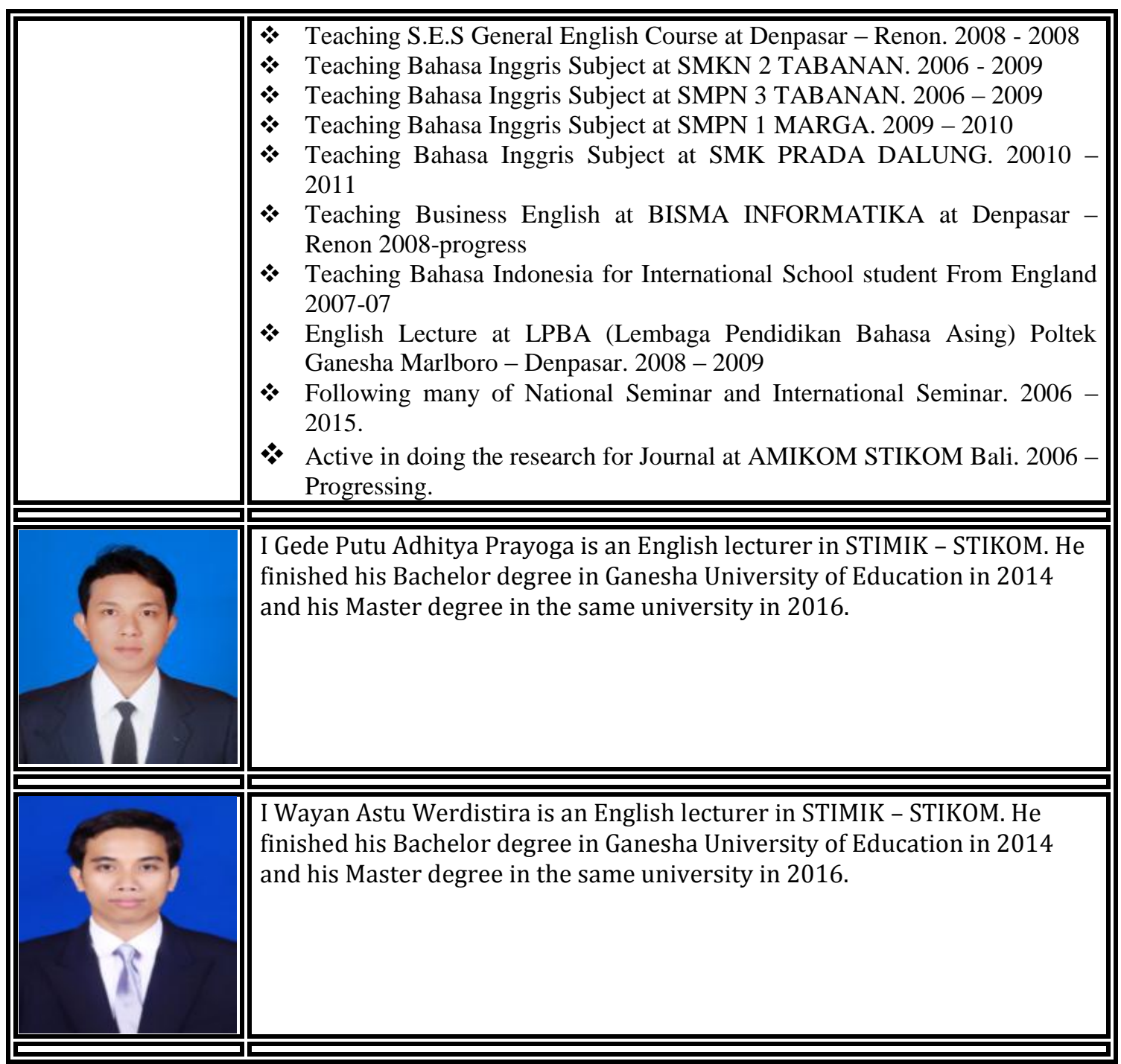

